\title{
The Amish-A People of Preservation and Profitability: A Look at the Amish Industry in Lancaster County, Pennsylvania
}

Joseph M. Harasta ${ }^{1}$

Professor

Communication Studies

Kutztown University of Pennsylvania

\begin{abstract}
Throughout much of their existence, the Amish remained relatively unknown and/or misunderstood by much of American society other than those who lived in areas with visible Amish communities. However, beginning in the second half of the twentieth century, the popularization of the Amish became a profitable commodity. With ever-increasing media exposure of the Amish during this time, some Amish communities were quickly becoming tourist destinations. It was clear by this point that the growing numbers of sightseers and lines of tour buses could be a moneymaker for businesses near the Amish communities. In many respects, the Amish during this time became a brand, representing a lifestyle that many Americans sought, if only on occasion - a bygone era when things were perceived to be simpler. Amish products and Amish imagery are now a viable commercial brand for everything from amusement parks to beer. This article examines the phenomenon of this "brand” in Lancaster County, Pennsylvania. Through analyses of interviews with Amish merchants, non-Amish businesspersons who profit from the Amish image, as well as the patrons of Amish stores, the following article provides a unique account of how the Amish image functions from multiple perspectives and the influence it has on consumers who financially support the Amish "brand."
\end{abstract}

\section{Keywords}

Lancaster County, Pennsylvania; entrepreneurialism; Amish; cottage industry; brand; industry; commercialism; tourism 


\section{Introduction}

Trollinger (2012) notes that when Amish-centered tourism “...makes reference to the Amish, they typically do so as if 'Amish' were like a brand like 'Levi' or 'Nike' or “Apple”, (31). The following study seeks to shed light on the use of the Amish way of life as a marketing tool in Lancaster County, Pennsylvania, which, for this study, is described as the Amish "brand." Though both Amish and non-Amish businesses are examined, this study is not a compare-andcontrast. Rather, it seeks to better explain the economic culture of a tourist destination, which succeeds primarily because of Amish-centered branding and tourism marketing.

\section{Lancaster County’s Transition into an Amish-Centered Tourism Destination}

Arguably, the popularity of the Amish is greater now than it has ever been in America. Television shows like Amish Mafia, Breaking Amish, and Amish: Out of Order have created an Amish "frenzy" both in the media, and, in turn, within American society. The simplicity and quaintness of their lifestyle seems to appeal to many Americans seeking an escape from the evergrowing stresses, fears, and complexities of the modern world. While the authenticity of these shows has come into serious question, there is no doubting their influence on the minds of millions of Americans, influential enough to motivate them to want to see the Amish close up and experience their lifestyle firsthand. However, even before today's widespread, national attention on the Amish from these more-recent programs, millions of eager tourists vied to pay for the experience in Lancaster County, Pennsylvania. Businesses began springing up in formerly isolated, rural communities. Soon, dusty back roads turned into multilane highways bringing millions of tourists, and their money, into Amish communities. The most famous, and accordingly most commercialized of them all, is Lancaster County Pennsylvania. Walbert (2002) described its development as such:

...tourist promoters and their national audience increasingly identified anything Pennsylvania Dutch, and indeed all of Lancaster County, with the Old Order Amish. That identification put Pennsylvania Germans and Lancaster Countians in a quandary. By identifying Lancaster and the Pennsylvania Dutch people with the Amish, by portraying the Amish as a people out of time, and by wrapping the whole package in a carnival atmosphere, tourist writers and promoters made the locals' struggle to reconcile tradition and progress more difficult (68).

During the 1980s, the greatest push in the development of tourist-centric planning took place, and today, Amish tourism is the largest and most developed in Lancaster County (Luthy 1994). In his writings on Lancaster County, Testa (1993) recorded one Amishman's comments on the region's growth:

You see, two hundred years ago, or more, our people came here to escape religious persecution in Europe, and in those days the countryside was mostly woods. Well, we 
helped to turn the land into what is now known as the garden spot of the world, but if this development keeps up, it looks as if we're going to be driven out again. This time it will not be religious persecution, it will be the persecution of prosperity (160).

This prosperity has come at a price for area Amish. Over 26,000 Amish now reside in Lancaster County, Pennsylvania. This oldest of existing Amish settlements has changed from one centered on family, faith, and farming to cottage industries, and it is one of the few Amish communities located in a county which is also classified as a metropolitan area (Donnermeyer, Anderson, and Cooksey 2013). Rich limestone soil and readily available water sources still make the area an agricultural oasis supporting flourishing grains, fruit production, and vegetable produce, as well as animal stock. Lancaster County is the most productive, non-irrigated county in the United States, which enabled the Amish to prosper in their traditional, agricultural-based lives (Testa 1993). However, rapidly accelerating since the early 1980s, the move from farmcentered to industrial work changed Amish life in Lancaster County, just as the county itself changed from rural to suburban, and ultimately to its current metropolitan classification. Steep rises in land costs caused by exorbitant offers from real estate developers and growing retail centers supporting the tourist masses forced the area's Amish off farms and into industries once considered unsuitable. Wishing to remain in Lancaster County, many Amish compromised (Kraybill 2008). Much of this compromise resulted in Amish entrepreneurialism that is as much a part of the Amish community in Lancaster County today as farming was just 30 years ago.

These entrepreneurial endeavors can be classified into three categories: home-based operations, mobile work crews, and larger shops (Kraybill 2008). Home-based operations are small shops selling baked goods, crafts, flowers and plants, etc., built in and around an existing Amish home and catering to tourists and Amish alike. Kraybill (2008) notes:

This mini revolution is the largest and most significant social change since the Amish arrived in Lancaster County in the 1700s. In the long run, the rise of business will disturb the social equality of Amish life by encouraging a three-tier society of farmers, entrepreneurs, and day laborers. Parents worry that youth, working a forty-hour week with cash in their pockets, will snub the traditional Amish values of simplicity and frugality. The new industries increase contact with the outside world, and such exchanges, over generations, will surely prompt more changes in Amish life (51).

While Lancaster County ranks just $22^{\text {nd }}$ as far as the highest proportion of Amish per capita in a United States county (Donnermeyer, Anderson, and Cooksey 2013, 101), it remains in many Americans' minds the unofficial Amish “capital.” Beginning in the mid-1950s, Lancaster County became a U.S. top ten tourist destination (Luthy 1994). A primary reason for Lancaster’s notoriety rests with the media. As early as the 1930s, newsreels and travelogues attracted people to Lancaster County to see the Amish. Nominated for eight Academy Awards, 1984's Hollywood blockbuster filmed in Lancaster County, Witness, starred Harrison Ford as a hardnosed Philadelphia police detective fighting for justice against the backdrop of Lancaster County’s 
Amish communities. Tourist numbers rose to over five million in the year following the film's release (Luthy 1994). Today, tourism in Lancaster County annually attracts over 10 million visitors (Trollinger 2012).

The "fame” of Lancaster County's Amish continues to evoke interest. In his seminal 1963 work, Amish Society, John Hostetler noted, "Yet, the Old Order Amish are not really representative of frontier America, despite the fact that the cosmopolitan American city-dweller may look upon them as islands of sanity" (322). As the world became more complicated, this "sanity" became more attractive to throngs of "city-dweller" tourists, and where better to find it than the most-famous and easy-to-find Amish “island,” Lancaster County, Pennsylvania? Meyers (2003) elaborates on this attraction:

When tourists purchase an Amish chicken, Amish candy or a bottle of Amish water, they truly believe that the water is somehow purer and the chicken and candy taste better because of the Amish label. The tourist is not only purchasing a product but is also purchasing the Amish ambience (110).

The marketing of Lancaster County as an Amish-centered tourist destination illustrates the commercial power that the Amish "brand" possesses. Without this Amish lifestyle appeal, Lancaster County would be just another rural community in eastern Pennsylvania. Naturally, because of its economic boon, Lancaster County embraces and stimulates tourism along with its greatest attraction, the Amish. Tourist regions such as Lancaster County still need to develop strategies if they want to be successful (Fagence 2001). For example, the Lancaster County tourism website, www.padutchcountry.com, illustrates the county's commercial embrace of the Amish. For instance, the tourist bureau's logo features a horse and buggy. It offers many Amishcentered itineraries including “Experience Amish Country,” "Quilters’ Paradise,” “The Amish and their Heritage," “The Amish Way of Life,” and “The Heart of Amish Country,” all featuring information on the multitude of Amish-related businesses. As an illustration, one of the mostpopular attractions, Amish Village, offers:

...a guided tour of an authentic 1840's Amish farmhouse and learn about today's Amish lifestyle. Then, after your farmhouse tour, explore our 12-acre village grounds, mingle with our Amish staff and say "hi" to Mr. Ed the horse. Even have your picture taken on a real Amish buggy. Have fun while learning something new with the area's only authentic Amish lessons, taught in our one-room schoolhouse (padutchcountry.com).

Retail and outlet shopping has expanded with tourism growth. Craik (2001) speculated that the tourism industry in Lancaster County was not entirely a result of the Amish. Other, diverse attractions such as Dutch Wonderland (an amusement park on Route 30) also draw people. However, would such attractions exist without Amish? Neighboring counties like Chester are similar to Lancaster, with the exception of an Amish population. Accordingly, the touristcentric development of Chester County is nowhere near the level of Lancaster County. Therefore, 
it appears that the tourism industry explosion is related to Lancaster's ability to attract visitors to its largest, first attraction. Fagence (2001) describes Lancaster County’s offerings as such:

There is widespread evidence of a general commitment to the commercial exploitation of the Amish theme, with developments which include allegedly authentic Amish farm visits, horse and buggy rides, extravagant Imax presentations, tours of the district with stopping points at Amish businesses, precincts and 'villages' of Amish businesses, static displays in one-room schools, and so on (13-14).

The Amish make Lancaster County a tourist destination. Without them as an attraction, the United States Census probably would have been slower to classify the formerly rural county as metropolitan. Because of this commercial culture, the county's landscape continues to grow and expand to accommodate the ever-increasing tourist industry demands. Mitchell (1998) suggests that this postmodern landscape results from tourist-centered marketing, which highlights the ideals of Amish / Old Order Mennonite life. However, Mitchell also found that this type of tourist-centered industry creates tension between the visitors and locals.

\section{Methods}

This study focuses on small, independent businesses located on major Lancaster County roadways, U.S. Route 30, for example, the main artery in Lancaster County (see Figures 1 and 2 for examples of businesses). Businesses operating at least ten years were most often selected. In these businesses, the researcher sought interviews with Amish merchants, non-Amish merchants using the Amish brand, and patrons. Twenty interviewees from each merchant group were selected. Some were from stand-alone businesses; others were collective, farmers' market style operations with many businesses in one facility. Patron interviews were short, ranging from five to ten minutes. In all, 50 patrons were interviewed. Interviews with the Amish and non-Amish merchants lasted up to 30 minutes. Whereas patrons quickly came and went from businesses, merchants set aside time to be interviewed. The researcher presented different sets of questions to each group, providing as diverse an analysis as possible. Field research and interview responses were recorded using pen and paper in order to provide consistency in recordkeeping, as Amish participants are liable to decline having interviews recorded (Hovinen 1982).

Data analysis focused on identifying repeated themes among the three groups. Questions asked and theme frequencies are presented in tables. While these tallies do not offer statistical significance, they do illustrate open response-based commonalities. More expansive and particularly illuminating quotes are also presented. Direct quotations from the respondents eliminates as much researcher influence / misinterpretation as possible. Amish responses are not intended to reflect the entire Amish community in Lancaster County, as individuals included actively seek interaction with tourists and therefore may hold different opinions about these interactions. 


\section{Figure 1: Dutch Haven}

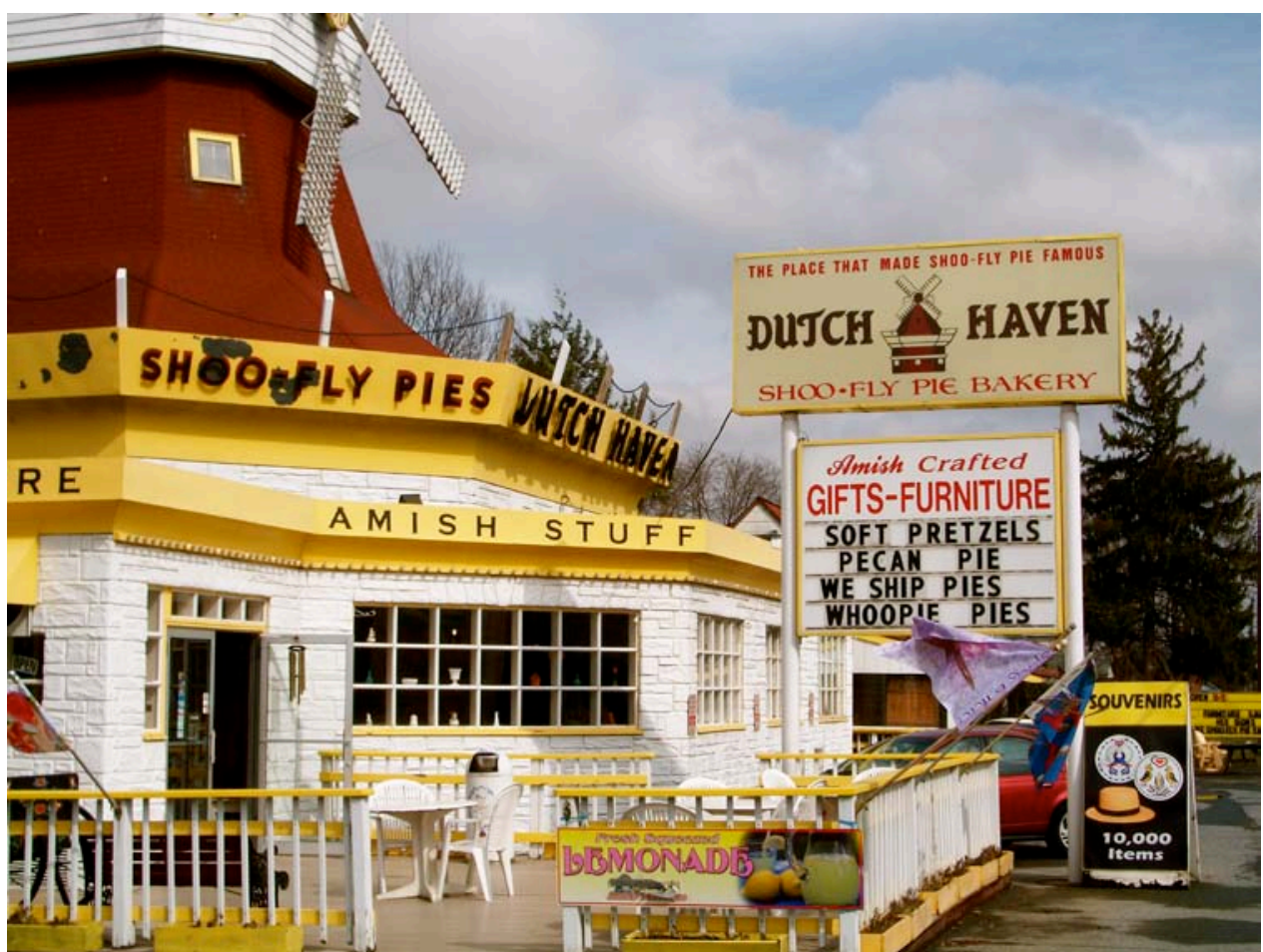

One of many non-Amish run, tourist-centered businesses located on Route 30 in Lancaster County. Note the sign advertising “Amish Stuff.”

\section{Figure 2: The Amish Farm and House}

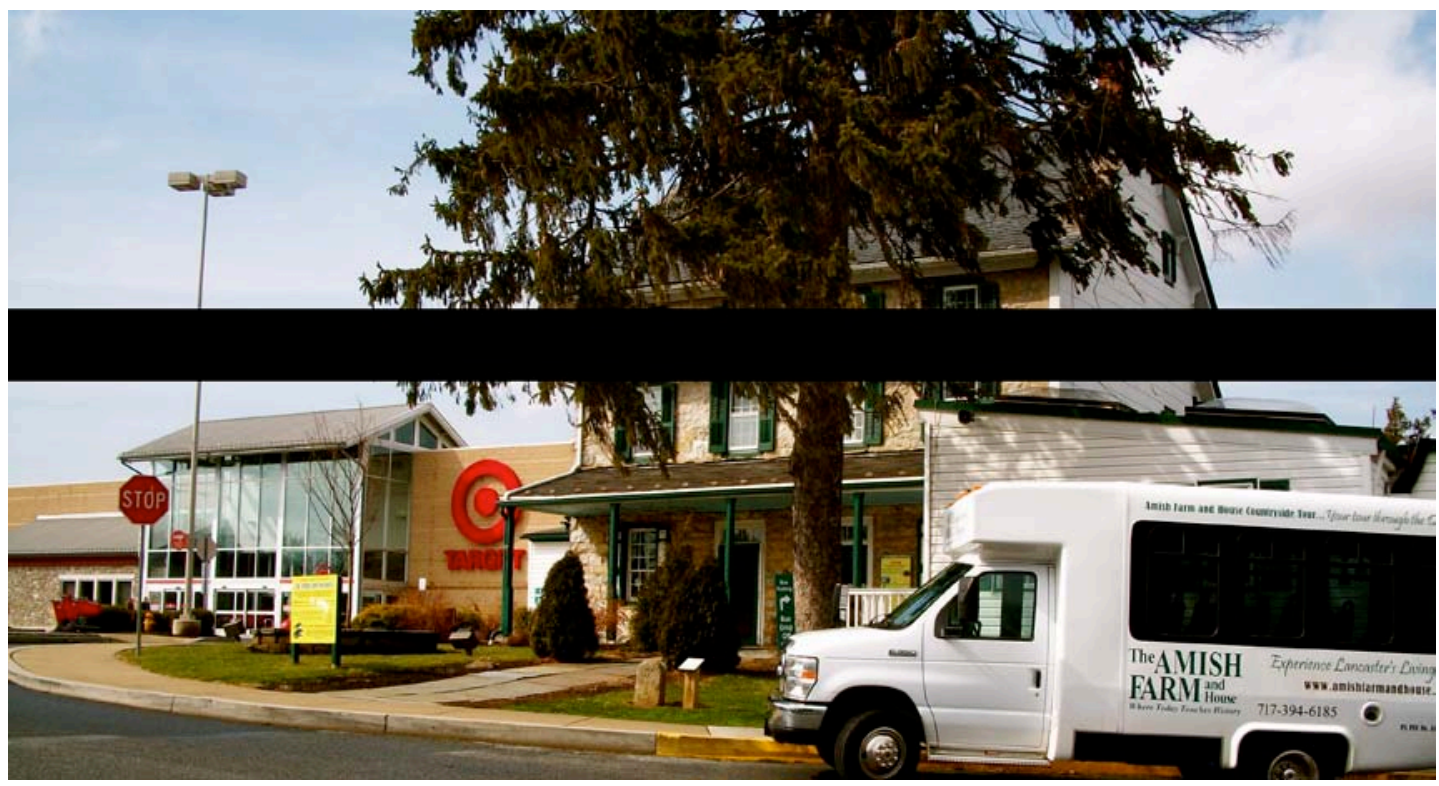

"The Amish Farm and House" touts itself as "Where Today Touches History," a reality illustrated here with the large shopping complex behind this "historical" attraction. It was also the first Amish attraction ever opened for tourists. 


\section{Results}

Interview answers from the three main group-Amish merchants, non-Amish merchants who sell Amish-related products / services, and the patrons of Amish businesses - are here organized and presented. Depending on respondents' available time, answers were sometimes short but to-the-point. Whenever possible, deeper probing was pursued, especially when asking business owners about perceptions of Amish branding and marketing. Overall perceptions of each group are presented first followed by detailed responses. Amish businesses included in this study entail a diverse industry ranging from large farmer's markets to small, roadside stands. Much of this diversity is related to the tourism industry of the area, as Amish-owned stores must diversify to meet the many wants of the tourists, from quilts and furniture to meats and preserves (Kreps, et al. 1997).

\section{General Sentiments from Amish Merchants}

Table 1 summarizes this section's results, including questions posed to Amish merchants, themes in their responses, and the frequency in which certain themes are mentioned. Amish merchants comment on Lancaster County's development as a tourism destination based primarily around an Amish theme, their futures in the region, their thoughts on the Amish lifestyle as a brand, and their relationships with non-Amish customers and non-Amish businesses. Tourism in Lancaster County is centered on the "peculiarity" of the Amish, and thus the source of tourists' interest in them (Buck 1978). The commercialization of the Amish lifestyle has grown tremendously in recent decades, so much so that it actually threatens the viability of the very tourism industry it created. More and more development using the Amish image to sell itself means less and less Amish lifestyle for tourists to observe. As an example, stores catering to the tourists now sit on land that was once an Amish farm. A strange dialectic exists in Lancaster County: tourists come to the area to see the Amish, but the Amish are being forced off their land by developers catering to tourists. As far back as 1963, John Hostetler observed, "The curiosity on the part of the tourist and the wake of commercialism may dissolve the Amish way of life more efficiently than any other means” (355). The Amish of Lancaster County certainly illustrate this point to a degree; however, in the face of it, they have been able to adapt and change their lifestyle to meet these challenges.

Nearly all interviewed Amish merchants accepted their lives as business owners selling goods directly to customers. However, several also indicated a fear of the family structure eroding through more interaction with society, and that it is more difficult for them to separate because of growing dependence on tourism. Kraybill (1994) noted, "For only by being separate people are they able to preserve the integrity of their tightly knit community” (33). Much discussion about Amish's interaction with the outside includes their concerns that it may lead to a lessening of core values. However, it is a way of life now. One merchant stated, "This is just the way things are these days. I saw it growing over the past few years, and now this is what we do." 


\section{Table 1: Interview Themes and Frequencies, Amish Merchants}

\begin{tabular}{l|l}
\hline & Advertising (18) \\
Where do you think the Amish brand & Television (15) \\
originated in Lancaster County? & Friends (13) \\
& Movies (13) \\
& Magazines (5) \\
& Newspapers (3) \\
\hline \multirow{3}{*}{ What do you think the future of the } & Fewer farms (19) \\
Amish in Lancaster County will be? & More families moving elsewhere (17) \\
& Less opportunities (11) \\
& More construction and welding work (9) \\
\hline \multirow{3}{*}{ What are your thoughts on the non- } & Friendly (18) \\
Amish patrons of your business? & Touristy (17) \\
& Confused (4) \\
\hline Wharried (3) \\
your business? & Stressed (2) \\
\hline How can you compete with those big & Food (candy, snacks like pretzels, ice cream, meats, \\
stores down the road (Route 30)? & pies, and bakery items) (19) \\
\hline
\end{tabular}

Another merchant commented, “As long as we're able to keep things going for our families, then this is what we'll have to do. You get used to it like anything else.” However, not all Amish merchants were as accepting. One elderly Amish man working at a produce market stated, "I think it's kind of sad to see our young ones having to go into these types of jobs. I'd like to see them all stay on the farm, but that's not possible for many of them, so here we are.” Interestingly, most of the younger respondents (teenage to mid-twenties) appeared completely accepting of their commercial-centered way of life. "I hear my grandparents talk about the old ways on the farm, but that's not what we're doing anymore. It's like we're changing, and the times aren't the same, so that's that." Another young Amishman commented, "If we could be on the farm, we probably would, but that's not possible anymore; it’s too expensive.” These responses confirm previous findings that non-traditional Amish work, like working the cash register at a store, presents a threat because of the husband's daytime absence from the home (Kraybill 1994; Kreps, et al. 1997), a concern especially among older Amish. However, when asked about their plans for the future, many younger Amish merchants seemed nervously optimistic. "Things seem to be going well here, but then you never know," commented one. "I think a lot depends on the competition down there,” referring to the large number of box and warehouse stores. 


\section{Amish Merchants Discuss Their Businesses}

As mentioned above, many acres of land previously devoted to agriculture now host fast food restaurants, outlet stores, and large box chains. The author questioned Amish merchants engaged in business-to-tourist work about this evolution. "I began seeing more and more of it about 20 years ago. That's when the bigger names came in and started pushing the small businesses out. Those big places could also buy as much land as they needed, and that's when you started seeing the place change," said one. Another said, "Well there's always been something down here [stores on Route 30]. Now they're everywhere. I don't know how much more they can put in, but they'll try."

While catering to the tourist trade will enhance the region's economic future, in the long term, the environment will erode (Mitchell 1998). Ironically, the attraction to the Amish lifestyle is also leading to its destruction, as farmland is developed and parceled. The area is becoming a victim of its success - too many people not finding what they are looking for because there are too many people looking for something that is no longer there. One merchant commented that many former Amish neighbors and friends moved in response to development. "About 20 years ago we had a lot more family farms and less traffic and people than today. But when the place started getting built up, then a lot of the old-timers decided they weren't going to be part of that, so a couple of them went off to Ohio and other places."

Over 30 years ago, Buck (1978) found that the Lancaster County tourist industry would strengthen the Amish's sense of community. However, present findings suggest that tourist industry growth is forcing Amish to relocate to more isolated areas while, at the same time,

presenting economic opportunities not seen in the area previously. As development connected to the tourist trade continues expanding, real estate available for Amish also diminishes.

When asked their thoughts about the Amish's future in Lancaster County, most senior respondents indicated that it would be up to the younger members to decide. "They're the ones who grew up with this. They don't really know no difference, so it's probably better for them this way. But, I don't know, I worry that there's too much here, and it's going to hurt them long term," stated one. "I see it being more of a way of life for them than it was for us. They seem to accept it as a way of life more," added another. A common theme was economic pressure. "During the summer we do alright, but later in the year it's a lot harder to make it. That's why a lot of the young folks also work in building and welding during that time. There's no real way they could do it otherwise," said one Amish merchant. "Well, everything's more [expensive] these days. To make it, you got to do more, and when the people aren't coming in, then it's a lot harder," said another. "I feel bad for [younger Amish]," said a female merchant. "They have a lot more pressure on them than we did. Trying to raise a family, keep things going, it’s not easy."

When asked about the non-Amish patrons / tourists to whom they cater, most respondents were appreciative of them. “That's why we're here, trying to provide them something. They're 
funny sometimes asking us questions and all. They seem to think we're not real or something,” remarked one. Hovinen (1982) also found Amish complained that they were treated as "oddities." However, most Amish here seemed content with their interactions with non-Amish, possibly because of their business-natured interaction. "We have a lot of people coming in here a couple times a week, so you start to speak with them and they to you, so you know, you start looking for them," commented another respondent. "I think it's good for us and them in a way. They get to see something interesting, I guess, and we need them too," said one young merchant. When asked about any interesting or uncomfortable interactions, most respondents said they were rare or never happen. "Sometimes you get the young kids in here on their phones, and they won’t even look at you, just keep looking at that phone the whole time," said one. "We don't get too many problems, sometimes though they'll just ignore you when you ask them something. For the most part, they come in and look around and usually go,” added another respondent.

When asked what products seem the best sellers, most respondents noted food items. "Candy and pretzels and chips and things like that do well. It comes and goes, too. Like we had a lot of meat and poultry awhile back [a recent holiday passed]. Sometimes they'll buy a quilt or towels, but they usually just look at that stuff more, expensive I guess," said a respondent. Many comments, however, noted a drop in customers over the years as the chain stores moved in. "It's definitely taken some people away. Those big places sell everything real cheap. My family goes there because of it, too," said one female respondent. "A lot of what we have is more local stuff," said another respondent pointing to produce.

When asked how they compete with larger stores, many Amish merchants noted they cater to tourists more. "They come here looking for us, so we give what we can. I'm not sure what they're expecting sometimes, but it helps to sell what they're looking for," commented one respondent, pointing to pies and baked goods. Mitchell $(1998,274)$ described this attraction as the "idealization of the countryside." Another respondent said, "Some of the newer places even build it to look like a barn or something. You know, what they think we're about.” Most Amish merchants interviewed seemed amused, yet also melancholy, about their dependence on nonagricultural-based means of livelihood. All, however, seemed resigned to accept it and make the best of it. Interestingly, much of the discussions about the new, national chain stores coincide with Hovinen’s (1982) findings:"Some local residents express increasing concern about what they perceive to be deterioration in environmental quality caused by the growth in the number of visitors and the man-made tourist landscape” (570).

\section{General Sentiments from Non-Amish Merchants Selling Amish-Related Products}

Unlike Amish stores that sell Amish-produced merchandise or products supporting Amish life, non-Amish merchants carry more products with symbolic associations with the Amish and the Pennsylvania Dutch. For example, souvenirs such as hex signs (often printed on particle board imported from China) and books on the Amish are popular items. This is well captured in a quote from Trollinger (2012): “...each of these Amish settled areas is now home to many 
restaurants, shops, festivals, and assorted paraphernalia that, despite use of the word 'Amish,' share little but proximity with Amish life and culture” (33).

Most non-Amish merchants expressed appreciation of Amish neighbors —albeit often because of opportunities offered via tourist revenues and customers. One noted, "Without them [Amish] we'd have to find something else to do.” Another remarked, “A lot of people come here to see their ways, and they need some place to stay, so all the better." "They have their stuff, and we have ours," commented one, adding, "there seems to be enough [customers] to go around." Both Amish and non-Amish merchants expressed displeasure with large, national chains. "It used to be that it was a small-time and homey place. Now we've got places like Target and Wal-Mart around and the fast food places make it hard to compete,” commented one merchant.

\section{Non-Amish Merchants’ Thoughts on Amish Branding and Marketing}

The "industrialization" of Lancaster County is a relatively new phenomenon. While the Amish were the original area attraction, the increase in tourism revenues has created a selfsustaining shopping and commerce industry. Outlet shopping, for one, is growing. Outlet stores may make no explicit connection between the brands they sell and the Amish, as Trollinger (2012) describes: “The silhouette of an Amish buggy does appear on one outlet mall sign, high above the parking lot, perhaps this is meant to connect bargain prices with Amish thrift” (31).

Questions posed to non-Amish merchants in Lancaster County centered on the development of this industry, the relationship between Amish and non-Amish businesses, the future of their businesses, and their views on using the Amish brand (Table 2). Fagence (2001) found that non-Amish businesses in Lancaster County try to directly connect with the Amish image. Here, too, non-Amish business owners and workers acknowledged that they do use the Amish image to market their products and services to tourists seeking the "Amish experience" regardless of the authenticity of the experience.

When asked about the Amish as a brand, many non-Amish merchants admitted the image’s “utility” but denied exploitation. “Most of us here are third, fourth generation, so we're not Johnny-come-lately. My family owned this business for years even before the big boys came here," said one respondent. "I think we'd be crazy not to stay true to our roots here, and the Amish are a part of it, so that's the way it is," said another. A follow-up question asked whether the non-Amish merchants felt as though they use the Amish image against the will of the Amish. "I've never had any of them come here and tell me to stop using the word Amish," said one merchant. "Most of us are friends or have ties with Amish families, and they have no problem with us and our business here," remarked another. "I can see the usefulness of them in bringing in customers," added one merchant. Interestingly, several respondents commented that they felt bad for the Amish and the changes to their way of life because of the commercial development of the area. "I see them sometimes sit for a long time [in their buggies] waiting to cross the highway 


\section{Table 2: Table 1: Interview Themes and Frequencies, Non-Amish Merchants Selling Amish-Branded Merchandise}

\begin{tabular}{l|l}
\hline $\begin{array}{l}\text { What are your thoughts on the Amish way of } \begin{array}{l}\text { It's what people want (17) } \\
\text { life being used as a brand to sell products? }\end{array} \\
\text { It's always been that way (14) } \\
\text { I think they're fine with it (12) } \\
\text { It's sad (2) }\end{array}$ \\
$\begin{array}{ll}\text { Can you talk about the commercial } \\
\text { development that's taken place in Lancaster } \\
\text { County? }\end{array}$ & $\begin{array}{l}\text { Mostly in the past 30 years (15) } \\
\text { Keeps growing (12) } \\
\text { Too much (9) } \\
\text { Running out of room (4) }\end{array}$ \\
\hline $\begin{array}{l}\text { How do you foresee the future of businesses } \\
\text { like yours here? }\end{array}$ & $\begin{array}{l}\text { Need less big stores and fast food (18) } \\
\text { We'll have to see (11) } \\
\text { On borrowed time (8) } \\
\text { We've been here this long (5) }\end{array}$ \\
\hline $\begin{array}{l}\text { How would you describe the relationship } \\
\text { between non-Amish businesses like yours and } \\
\text { the Amish-run ones? }\end{array}$ & $\begin{array}{l}\text { We're both struggling (17) } \\
\text { We have the same problems (14) } \\
\text { We work together for the same things (10) }\end{array}$ \\
\hline
\end{tabular}

here. Everyone just zooms by them," said one merchant regarding traffic increases. "Seems kind of like they're freaks or something for everyone to come and gawk at,” said another.

Regarding the development of the Amish as a revenue-generating source in Lancaster County, many non-Amish merchants commented that, similar to the Amish themselves, it began mostly over the past 20 to 30 years. "I remember back in the "70s this was all farmland and mostly locals, especially during the winter. Now it's all grown up, and everyone's here all the time," said one respondent. "It really picked up with the opening of the outlet stores and strip malls out here. Used to be just a couple of motels, some restaurants, and farms, not anymore," said another. Most non-Amish merchants noted the benefits and drawbacks to increasing commercialization. "It's nice to have all these people, but sometimes, I wish it were like it was," said one. "[Lancaster County officials] say that it brings in a lot of revenue and tax breaks with these [national chains], but I'm not sure if it's worth it," said one merchant. "A lot of us smaller places have been forced out because of the new places along the highway. It's becoming like a tourist trap in some ways. That's sad because it used to be real quaint and peaceful here,” said one merchant.

With this increasing development, many non-Amish merchants seemed less-than optimistic about the future of small, local businesses. "Some of them will just be bought out like what's already happened along the big roads, but when that's all taken up, they'll [chain stores] move out into the side roads too I bet," said one. "The problem is there's too many places now. There used to be a few restaurants, some shops, and a hotel here and there. Now there's ten of everything, and the smaller places just can't keep up," commented one respondent. "We're sort 
of in a catch-22. A lot of people, but fewer customers if that makes sense, at least for us," said one merchant on the dichotomy of the area's commercial centers. "The old places like the market [Lancaster Central Market] will be around because it attracts locals and tourists. Problem is a lot of us depend on a few months of tourism, and if those months are bad, our whole year is bad," remarked one. When asked whether the economy was at fault rather than the development of the county, most respondents admitted that the recession had taken a toll, but business was slowing before it as well. "When no one has any money, it's always bad. It's been worse these last few years because of it, no doubt,” said one. "Business hasn't been that great for a long time, not just since '08," said another. The shared problem of increasing competition from large chain stores among Amish and non-Amish merchants seems to have created a commonality between them.

When asked about relationships with Amish-run businesses, many commented that they both share commonalities. "They work hard, and we work hard. We could all be ok if there were less pressure from the big companies coming in," said one respondent. "A lot of us feel the same way. We all talk about the same stuff, and we all have the same stuff to work with," said another. "Usually [Amish] like to sell their items to the public at home, so they don't really take too much from us," commented one merchant. When asked about the competitiveness between Amish and non-Amish businesses, many non-Amish merchants remarked that they've found ways to work together. "The Amish, you know, make a lot of stuff themselves. You'll find most of the stores here sell those products too even though you won’t see an Amish anywhere there,” said one.

\section{General Sentiments from Amish Business Patrons}

To understand the phenomenon of Amish branding in Lancaster County more fully, the patrons of Amish-run businesses must be considered. Customers were asked questions about why they patronize such markets over their non-Amish competitors. Table 3 summarizes this section's results, including questions posed to Amish store patrons, themes in their responses, and the frequency in which certain themes are mentioned.

\section{Table 3. Common Themes from Interviews with Amish Merchants' Patrons in Lancaster County, Pennsylvania}

\begin{tabular}{l|l}
\hline $\begin{array}{l}\text { Why do you prefer the Amish } \\
\text { stores over the non-Amish } \\
\text { businesses? }\end{array}$ & $\begin{array}{l}\text { It's part of the experience in Lancaster (40) } \\
\text { They have unique items (39) } \\
\text { The quality (39) } \\
\text { I like the people here (24) } \\
\text { It helps them (16) }\end{array}$ \\
$\begin{array}{l}\text { Do you believe the Amish image is } \\
\text { being exploited to make money? }\end{array}$ & $\begin{array}{l}\text { I think they like selling their products (45) } \\
\text { It's part of the culture here (34) } \\
\text { I don't think it's right unless it benefits them (19) }\end{array}$ \\
\hline
\end{tabular}


In Lancaster County, the authenticity of tourist experience seems unimportant to many patrons of Amish businesses. Walbert (2002) wondered, "If there was a place for the real Dutch Country in the second half of the twentieth century, it was unclear what it might be” (100). Lancaster County visitors appear more interested in simply the experience of connecting to nostalgia. Most of the questioned Amish-run businesses' patrons commented that they enjoyed the experience of shopping at the Amish stores. Additionally, they stated that the products and customer service were of better quality than non-Amish businesses. Interestingly, several patrons also felt they were helping the Amish. Others stated that they wanted to "see the Amish for themselves." Over 30 years earlier, Hovinen (1982) found similar results: visitors wanted to see the Amish in cultural activities like faming with horses and mules. However, these sights are becoming increasingly difficult to find because of development.

\section{Amish Merchants' Patrons Discuss Their Experiences at Amish Businesses}

The Amish are a critical element to Amish country tourism efforts, as described by Trollinger (2012). Respondents indicated that the Amish and their related products (whether authentic or not) are what bring them to Lancaster County. Hostetler (1963) had asserted that tourism in Amish country offers little-to-no authentic Amish experiences, and that the tourists themselves were also lacking in character. Responses from customers of both Amish businesses indicated little concern over authenticity; rather, they stated convenience of shopping and "hitting the main spots" on Route 30 influenced their visits most. Accordingly, present offerings meet their search for an Amish "experience” with little interest in education about the Amish lifestyle.

Nevertheless, when asked why they chose to use Amish-run businesses, many respondents cited product and service quality as well as the experience. "We come here special for the atmosphere. It's like something my grandma would've went to,” said one patron. "I enjoy the experience, and I trust them more than the other places," commented another. "It's like going back in time. I like that," said one patron. "We come here every time we're in Lancaster. It's kind of like a tradition," commented one. "The people here are more friendly than the regular places," said one patron referring to the non-Amish stores. "It's just a better feeling in these places. The people are friendlier and care more," said another patron. "When you come to Lancaster, you have to come here. It's what it's all about," remarked one. Another commented, "We don’t have things like this back home. There’s something about it that's different. Better.”

Many patrons questioned commented that they thought the quality of the products and the customer service of the Amish-run businesses was better than non-Amish counterparts. "The things here are handmade. They last longer," said a patron. "I like the fact that the people selling the items are the ones who made them," said another. "Everything here is better. They have stuff you can't get anywhere else,” said yet another. "The selection of different things is neat. I don't see this stuff at home," said one about the canned goods. "The people here are real nice. They care more about what they do,” said one. “They become like family after awhile. Even though I 
don't get the chance to come here too often, they always seem to remember me," said one. "I like the way they care about you. They take what they do seriously and care more," said a respondent. "We like the way they treat you. They seem to respect you more and are more helpful,” commented a couple. “The kids like seeing this. It's an experience for them getting the things they can't at home,” remarked one patron.

An interesting occurrence when questioning patrons was the common response of patronizing Amish businesses to help them. "They work so hard. We like to help keep them going,” said one patron. "They're always there. These big places don’t need the money as much," said another. "I think they appreciate it more. The workers here can use the money because it's all they have," commented a patron. "We try to help them out by shopping here over the other guys. It's better anyway," said one customer. "I like the fact that we're doing something to help them,” commented another. These findings support Meyers' (2003) finding that when tourists consume Amish-related products, they also feel they consume the purity of Amish life.

When questioned about Amish branding for commercial purposes, many patrons indicated that they did not consider it when shopping. "I don't think there's any problem. They need the work, so it's fine with me," said one patron. "I think they like it. It's what everyone here comes for," added another. "This is the only place where they can sell their things," remarked one about perceived limitations of Amish mobility. However, some patrons indicated they thought that the Amish should not be used for commercial purposes unless they desired. "Some of these places say they're Amish, but you go in there, and it's just Amish-related junk. I don't think that's right. That's why I come here," commented one patron. "Sometimes it seems like overkill with jamming that stuff down your throat,” said another. Generally, though, most patrons saw no problem with Amish imagery being used for commercial purposes.

\section{Discussion}

Interviews from Amish merchants suggest a grudging acceptance of the new Lancaster County lifestyle centered on businesses and outside, non-farming work. Many younger Amish expressed acceptance of it, whereas older Amish workers longed days before tourism changed the landscape. In Holmes County, Ohio, Kreps, et al. (1997) found that Amish preferred tourists leave, but because they cannot change that, Amish accept and even use the tourist industry as a livelihood. In Lancaster County, Amish similarly use tourism as a livelihood with some reluctance. Businesses' owners and workers do enjoy interacting with non-Amish customers. Interestingly, most did not seem concerned that these interactions might negatively influence their lifestyle. The Amish also expressed what they understood these customers sought: Amish products and an "experience" through interactions with them.

Nevertheless, the Amish indicated that their changes in lifestyle will continue to grow, affirming other results that the Amish lifestyle must adjust to economic demands (Smith 1989). Products centered around the Amish image and brand, mostly food items relating to the 
Pennsylvania Dutch such as pretzels and canned goods, seem to harken back to what many patrons thought was a simpler time and way of life. Despite the success of many Amish-run businesses, the chain and box stores worried many small business owners. Jeong (2013) found that Amish businesses could thrive because of connections to non-Amish tourist trade agents. Accordingly, many Amish-run business owners seemed to understand that they needed to cater to the wants of the tourist trade by creating atmospheres that met the expectations of these customers, stores that have a "Pennsylvania Dutch" flavor.

Those business owners and employees that market Amish-related or Amish-made products but are not Amish-run shared many similarities to Amish counterparts. These individuals respected the Amish greatly. Buck (1978) found that in Lancaster County, "The local area cannot begin to meet the tourist demand for 'a little something from an Old Amish home!'” This certainly seems true in 2014, too. Non-Amish businesses cater to and develop products relating to the Amish for tourist customers. However, many products would never be found in an “old Amish home," but the customers do not seem to make this distinction.

Amish business owners understood the importance of the Amish "industry" on the county's economics and the tourists it brings to their businesses. They also shared the same concerns over the large, national encroaching chain stores. Non-Amish merchants did not see a conflict with using the Amish image as a brand to market their products and services (horse and buggy rides, for example). Like the Amish-run business owners, non-Amish owners understood and used that image as a marketing tool, albeit more explicitly and overtly than the Amish.

Patrons of both Amish and non-Amish-run businesses expressed little concern using the Amish lifestyle as a money-making tool, but rather saw it as mutually beneficial. Some patrons sought out Amish stores specifically because of this attraction, looking for interactions with "real" Amish and seeking their products. Patrons seemed ignorant or disinterested in the fact that most products were not Amish-made. Just relating to the Amish was enough. Horse and buggy models and cookbooks, for example, worked just as well as handmade quilts from a real Amish farmhouse. Those patrons seeking out Amish-run businesses, however, noted the importance they put on helping out the Amish by patronizing their establishments. Meyers (2003) found that visitors to Amish communities are not there simply to learn Amish culture, but are ultimately consumers of the culture. Responses from Amish business patrons here echo this point: it is what patrons expect from the Lancaster experience. They indicated that the products, especially food items, were better than non-Amish brands, and that they trusted the Amish merchants more than the large department stores. One wonders if patrons would say a factory-made jar of preserves with its label replaced with a handwritten one tastes better because it came from an Amish store.

Overall, the Amish brand is alive and well in Lancaster County, even though the encroaching national chains are worrisome to Amish and non-Amish business owners. Hovinen (1982) speculated that Lancaster County's decline would not be significant because of the area's accessibility, effective planning, and the ignorance of tourists that the area is now a tourist 
location designed for them. This study's findings support that assertion. Lancaster County's commercial tourism industry has continuously expanded since the mid-1950s. Buck (1978) speculated that, "Amish life will be ultimately engulfed and emulsified by the socioeconomic impact of the tourism industry” (224). However, the Amish seem to have accepted, even embraced, the tourism industry, at least those relying on it. The development of Amish-run businesses in Lancaster County catering to the tourism trade provides a means for livelihoods in an expensive area. Yet, the development and success of this industry is a catch-22 for the Amish. It presents them with new, more diverse ways of earning a living, but because of it, it also takes them from the traditional, farm-centered lifestyle that most of them seek.

The Amish of Lancaster County will continue to work in non-traditional fields such as those studied here. The Amish will continue to cater to the masses of tourists each year. Those who choose not will leave the county for more traditional Amish lifestyles. This finding does not support Buck and Alleman's (1979) prediction that the tourism industry will not affect the Amish community or create land use issues. However, the commercial growth of the county in the 30 years since that study has forced the Amish into new, non-traditional industries or to new Amish communities elsewhere. Bennett (2003) found that “...land use issues have been at the heart of all of the challenges faced by the Old Order Amish” (159). Because of the increasing population, land prices, and dependence on the tourism industry, the Amish lifestyle will continue to change from the traditional, farm-centered way of life to one that more closely mimics that of the "English.” This phenomenon seems consistent with the evolution of other Amish communities coping with their own tourism industries and the demands it places on them (Buck 1978; Kreps, et al. 1997). However, Amish determination to maintain their lifestyle has helped them evolve and survive. Bennett (2003) found that the Amish social viability is at the heart of their ability to resist destructive changes. Accordingly, Lancaster County Amish are also resisting the destructive changes that tourism presents. By adapting and accepting the tourism boom of the past few decades, many Amish are not only surviving the challenges to their lifestyle but also flourishing by strategically managing them.

While this study analyzes the present Amish-themed commercial culture in Lancaster County, Pennsylvania, it does not provide a thorough picture of the industry's evolution. A study focusing on an Amish settlement beginning to experience an Amish-centered tourism industry may more clearly illustrate how an area becomes “industrialized” despite its rural beginnings.

\section{Endnote}

${ }^{1}$ Contact information: Joseph Harasta, Communication Studies, Kutztown University of Pennsylvania, Room 424 Old Main, Kutztown University of Pennsylvania, Kutztown, Pennsylvania 19530; harasta@kutztown.edu 484-646-4357 


\section{References}

Bennett, Edward D. 2003. "Emancipatory Responses to Oppression: The Template of LandUse Planning and the Old Order Amish.” American Journal of Community Psychology 31(1/2):157-171.

Buck, Roy C. and Ted Alleman. 1979. “Tourist Enterprise Concentration and Old Order Amish Survival: Explorations in Productive Coexistence.” Journal of Travel Research 18(1):15-20.

Buck, Roy C. 1978. "Boundary Maintenance Revisited: Tourist Experience in an Old Order Amish Community.” Rural Sociology 43(2):221-234.

Craik, Jennifer. 2001. “Cultural Tourism.” Pp. 113-139 in Special Interest Tourism, edited by Norman Douglas, Ngaire Douglas, and Ros Derrett. Brisbane: John Wiley.

Donnermeyer, Joseph, Cory Anderson, and Elizabeth Cooksey. 2013. “The Amish Population: County Estimates and Settlement Patterns.” Journal of Amish and Plain Anabaptist Studies, 1(1):72-109.

Fagence, Michael. 2001. "Cultural Tourism: Strategic Interventions to Sustain a Minority Culture.” Journal of Tourism Studies 12(2):10-21.

Hostetler, John. 1963. Amish Society. Baltimore, MD: Johns Hopkins University Press.

Hovinen, Gary R. 1982. “Visitor Cycles: Outlook for Tourism in Lancaster County.” Annuals of Tourism Research 9:565-583.

Jeong, Seonhee. 2013. “The Role of Social Capital for Amish Entrepreneurs in Pursuing Informal Economic Opportunities.” Journal of Amish and Plain Anabaptist Studies 1(1):127-166.

Kraybill, Donald. 2008. The Amish of Lancaster County. Mechanicsburg, PA: Stackpole Books.

Kraybill, Donald. 1994. “The Amish Encounter with Modernity.” Pp. 21-33 in The Amish Struggle with Modernity, edited by Donald Kraybill and Marc Olshan. Hanover, NH: University Press of New England.

Kreps, George M., Joseph Donnermeyer, Charles Hurst, Robert Blair, and Marty Kreps. 1997. "The Impact of Tourism on the Amish Subculture: A Case Study.” Community Development Journal 32(4):354-367. 
Luthy, David. 1994. “The Origin and Growth of Amish Tourism.” Pp. 113-219 in The Amish Struggle with Modernity, edited by Donald Kraybill and Marc Olshan. Hanover, NH: University Press of New England.

Meyers, Thomas J. 2003. “Amish Tourism: 'Visiting Shipshewana Is Better Than Going to the Mall.”” Mennonite Quarterly Review 77(1):109-126.

Mitchell, Clare J. 1998. “Entrepreneurialism, Commodification, and Creative Destruction: A Model of Post-Modern Community Development.” Journal of Rural Studies 14(3):273286.

“PA Dutch Country.” Amish Village. Accessed September 23, 2013

(http://www.padutchcountry.com/members/amish_village1.asp).

Smith, Michael. 1989. Behind the Glitter: The Impact of Tourism on Rural Women in the Southeast. Lexington, KY: Southeast Women’s Employment Coalition.

Testa, Randy M. 1993. After the Fire: The Destruction of the Lancaster County Amish. Hanover, NH: University Press of New England.

Trollinger, Susan L. 2012. Selling the Amish: The Tourism of Nostalgia. Baltimore, MD: Johns Hopkins University Press.

Walbert, David. 2002. Garden Spot: Lancaster County, the Old Order Amish, and the Selling of Rural America. New York: Oxford University Press. 